\title{
Sweden: Non-binding Rules against the Pandemic - Formalism, Pragmatism and Some Legal Realism
}

\author{
Henrik WENANDER*
}

\begin{abstract}
Swedish measures to fight the spread of COVID-19 differ from the strategies used in other comparable countries. In contrast to the lockdown approach that has been applied in many European countries, the Swedish strategy has been based to a substantial extent on individuals taking responsibility under non-binding recommendations. This contribution explores the Swedish strategy from a constitutional and administrative law perspective, highlighting the tension between the formalist system for delegating norms under the Swedish Constitution and the pragmatic use of non-binding rules such as the "General Recommendations" adopted by the Public Health Agency. The article concludes that the official use of soft law instruments is confusing from a legal perspective, because nonbinding rules do not offer the traditional formal mechanisms for legal protection, the publication of norms or accountability. The legal-realist approach of the Supreme Administrative Court's case law, however, has the potential of balancing some of the unfortunate effects arising from the Swedish combination of formalism and pragmatism.
\end{abstract}

\section{INTRODUCTION}

Swedish measures to limit and prevent COVID-19 differ from the strategies used in other comparable countries. ${ }^{1}$ In contrast to the lockdown approach that has been used in many European countries, Sweden has applied a strategy based to a substantial extent on individuals taking responsibility under non-binding recommendations. The Swedish method has received considerable attention in international discourse. ${ }^{2}$ Notably, the

\footnotetext{
Lund University, Sweden; email: Henrik.Wenander@jur.lu.se. This work was supported by the Swedish Foundation for Humanities and Social Sciences (Riksbankens Jubileumsfond) within the project "The Constitutional Role of Public Administration in the Nordic Countries: Democracy, Rule of Law and Effectiveness under European Influence" under grant number P18-0532:1. The article considers developments until August 2020.

1 M Paterlini, “'Closing borders is ridiculous': the epidemiologist behind Sweden's controversial coronavirus strategy Anders Tegnell talks to Nature about the nation's 'trust-based' approach to tackling the pandemic" Nature (21 April 2020) <www.nature.com/articles/d41586-020-01098-x> (accessed 30 November 2020); I Cameron and A Jonsson Cornell, "Sweden and COVID 19: A Constitutional Perspective" Verfassungsblog (7 May 2020) $<$ verfassungsblog.de/sweden-and-covid-19-a-constitutional-perspective> (accessed 30 November 2020).

2 Eg T Wheeldon, "Sweden's COVID-19 strategy has caused an 'amplification of the epidemic"' France24 (17 May 2020) <www.france24.com/en/20200517-sweden-s-COVID-19-strategy-has-caused-an-amplification-of-theepidemic > (accessed 30 November 2020); M Olsen, “Sweden's coronavirus strategy: Right or wrong?" Euronews re-use, distribution, and reproduction in any medium, provided the original work is properly cited.
} 
measures also differ from those of the other Nordic countries of Denmark, Finland, Iceland and Norway. This is remarkable because the Nordic legal systems often provide similar solutions to societal problems. ${ }^{3}$

This contribution explores the use of non-binding instruments ("soft law") in Sweden from a constitutional and administrative law perspective. The concept of "soft law" is not used in national Swedish law; in fact, there is no term in Swedish for this phenomenon. This article, therefore, discusses the use of non-binding instruments, rather than "soft law".

At the time of writing in August 2020, the Swedish pandemic death toll was considerably higher than that of neighbouring Nordic countries. It has been suggested that the Swedish strategy, including using recommendations rather than binding norms, may account for part of this difference. ${ }^{4}$ Given the legal focus and methodology of the article, it is beyond its scope to assess the possible causal relationship between the Swedish use of non-binding rules and the spread of the virus. Still, from a legal point of view, the far-reaching use of non-binding rules by Sweden may be of interest to other countries.

As a theoretical background, a view of Swedish legal culture may be useful in order to put the Swedish measures against COVID-19 in a wider context. Comparative legal scholarship has described Swedish law as part of the Nordic legal tradition (the "Nordic legal family"). Among the features of this legal tradition is the focus on written legislation as the expression of the will of the democratically legitimate legislator. In this way, the Nordic legal systems are based on a high degree of trust in the wisdom and reasonableness of public bodies, following a notion of "the good state". ${ }^{5}$ These tendencies are clear in Swedish legal mentality. Legal scholarship has concluded that historical developments have fostered a collectivist culture, where public authorities can rely on citizens adhering not only to the letter but also to the spirit of given rules in good faith. ${ }^{6}$ To put it differently, the state has not traditionally been seen as an enemy intruding into the privacy of individuals and families, but rather as a source of support. ${ }^{7}$

When it comes to Swedish constitutional law, the written constitution consists of four fundamental laws, these being, in chronological order, the Act of Succession 1810, the Freedom of the Press Act 1949, the Instrument of Government 1974 and the Fundamental Law on Freedom of Expression 1991. Of these, only the Instrument of Government is of interest here, since it regulates the constitutional system, including state organs,

(22 April 2020) <www.euronews.com/2020/04/22/sweden-s-coronavirus-strategy-right-or-wrong > (accessed 30 November 2020).

3 P Letto-Vanamo and D Tamm, "Nordic Legal Mind" in P Letto-Vanamo et al (eds), Nordic Law in European Context (Springer 2019).

4 T Ellingsen and J Roine, "Sweden and the Virus: Public Policy and the Swedish Model. What was the Swedish government's approach to the pandemic, and how was it received in Sweden?" (preprint from Sweden Through the Crisis, forthcoming publication by SIR, the Stockholm School of Economics Institute for Research) <www.hhs.se/ en/research/sweden-through-the-crisis/sweden-and-the-virus $>$ (accessed 30 November 2020).

5 Letto-Vanamo and Tamm, supra, note 3, p 8; H Krunke and B Thorarensen, "Introduction" in H Krunke and B Thorarensen (eds), The Nordic Constitutions. A Comparative and Contextual Study (Hart 2018) pp 7 f; U Bernitz, "What is Scandinavian Law?" (2007) 50 Scandinavian Studies in Law 14, $15 \mathrm{ff}$.

6 S Strömholm, "General Features of Swedish Law" in M Bogdan (ed), Swedish Legal System (Norstedts Juridik 2010) p 9.

7 cf J Nergelius, Constitutional Law in Sweden (2nd edn, Wolters Kluwer 2015) p 11. 
protection of human rights, forms of legislation and constitutional control. The Instrument of Government relies on an idea of undivided popular sovereignty and not on a separation of powers. ${ }^{8}$ This lack of constitutional conceptualisation of the roles of the state powers is of significance for understanding the peculiarities of Swedish public law in terms of the COVID-19 crisis.

The focus on written law is clearly expressed through the principle of legality, which holds a predominant position in constitutional and administrative law thinking. The core of this principle is a requirement of support in written legislation for public bodies to act, especially concerning measures that are burdensome to the individual. ${ }^{9}$ The respect for the legislature is also indicated by the wide acceptance of the use of legislative materials (travaux préparatoires) for the interpretation of legislation. ${ }^{10}$ At the same time, a certain form of "pragmatism" is often mentioned as specific to the Nordic legal systems, including Sweden's system, in the sense that legal reasoning traditionally rests more on practical considerations and less on the deduction of solutions from abstract general principles. ${ }^{11}$ In this way, Swedish legal thinking may be situated between a formalist adherence to written law and the pragmatic solution of problems.

Swedish legal thinking has further been influenced by Scandinavian legal realism. In short, this line of legal philosophy was aimed at distancing law from allegedly metaphysical speculations on morals, natural law and legal concepts. Instead, it promoted considerations of real-world conditions as guiding principles for understanding law. This theory was very influential in the development of Swedish legal scholarship during the twentieth century. ${ }^{12}$ As will be described below (Section IV.1), this theory may be relevant to understanding the development of legal protection against non-binding measures.

As to the outline of the article, the first four sections below provide a general background to the use of non-binding rules in the COVID-19 pandemic in Sweden. This includes an account of the constitutional framework (Section II), a brief description of the rules and principles for adopting legally binding norms in Sweden (Section III), some comments on the general legal framework for using non-binding rules (Section IV), and a discussion on legal protection against non-binding rules (Section V). After this, the use of non-binding rules in the pandemic is discussed in the central part of the article (Section VI). In Section VII, some concluding remarks are made regarding the tension between pragmatism and formalism in the legal measures to counter COVID-19 in Sweden. Also, the potential of the legal realisminspired case law of the Supreme Administrative Court - at the time of writing not yet used in relation to measures in the pandemic - is highlighted.

\footnotetext{
8 Nergelius, supra, note 7, pp 24, 31 f; Instrument of Government (Regeringsform) 1974, Ch 1 Art 1.

9 Instrument of Government 1974, Ch 1 Art 1 and Ch 8 Arts 2 and 3.

10 Nergelius, supra, note 7, pp $31 \mathrm{f}$.

11 H Krunke and B Thorarensen, "Introduction" in H Krunke and B Thorarensen (eds), The Nordic Constitutions: A Comparative and Contextual Study (Hart 2018) pp 7 f; U Bernitz, "What is Scandinavian Law?" (2007) 50 Scandinavian Studies in Law 14, 15 ff.

12 Letto-Vanamo and Tamm, supra, note 3, pp 12 f; J Reichel, "European Legal Method from a Swedish Perspective Rights, Compensation and the Role of the Courts" in U Neergaard et al (eds), European Legal Method - Paradoxes and Revitalisation (DJØF Publishing Copenhagen 2011) pp $246 \mathrm{ff}$.
} 


\section{Constitutional framework}

The legal scope for the use of non-binding rules to counter the COVID-19 pandemic in Sweden is dependent, of course, on the constitutional framework. Sweden is a parliamentary democracy resting on the constitutional concept of popular sovereignty, with the Riksdag (Parliament) being the foremost representative of the people. ${ }^{13}$ The government is currently a minority government tolerated by the Riksdag under the socalled "negative parliamentarianism" of the Instrument of Government. ${ }^{14}$

The constitutional status of the administrative agencies differs from that found in most Western democracies. It is sometimes referred to as the "Swedish administrative model". ${ }^{15}$ However, Finnish constitutional law is based on a similar system. ${ }^{16}$ This model entails that all administrative agencies are organised outside governmental ministries as free-standing public bodies, albeit under the general leadership of the government. ${ }^{17}$ In the COVID-19 crisis, the most important administrative agency in the field is Folkhälsomyndigheten (the Public Health Agency), which has the national responsibility for coordinating measures against communicable diseases and taking necessary initiatives. Like other Swedish administrative agencies, the Public Health Agency is led by a Director General, who is appointed by the government. ${ }^{18}$ The Director General appoints a State Epidemiologist, who is responsible for coordinating the monitoring and analysis of the development of communicable diseases and protection against them generally. ${ }^{19}$ Other important administrative agencies in the COVID-19 crisis have been the Myndighet för samhällsskydd och beredskap (the Civil Contingencies Agency, responsible on a general level for assisting local government and other authorities in matters of public safety and civil defence $)^{20}$ and Socialstyrelsen (the National Board of Health and Welfare, responsible for assisting and coordinating the providers of health care on the local and regional levels). ${ }^{21}$

All Swedish administrative agencies act in their own name, and not on behalf of the Government or an individual minister. It follows from the Instrument of Government that neither the Government and its ministers nor the Riksdag may give directions to the authorities in individual matters applying provisions of Acts of Law or making

13 Instrument of Government 1974, Ch 1 Art 4.

14 Instrument of Government 1974, Ch 6 Art 4; Nergelius, supra, note 7, p 72; on the concept of "negative parliamentarianism", T Möller, "The Parliamentary System” in J Pierre (ed), The Oxford Handbook of Swedish Politics (OUP 2015) pp $115 \mathrm{f}$.

15 P Hall, "The Swedish Administrative Model" in J Pierre (ed), The Oxford Handbook of Swedish Politics (OUP 2015) pp $300 \mathrm{f}$.

16 O Mäenpää and N Fenger, "Public Administration and Good Governance" in P Letto-Vanamo et al (eds), Nordic Law in European Context (Springer 2019) p 164.

17 Instrument of Government 1974, Ch 12 Art 1.

18 Förordning med instruktion för Folkhälsomyndigheten (Ordinance with Instruction for the Public Health Agency, 2013:1020) ss 21 and 23.

19 Arbetsordning för Folkhälsomyndigheten (Rules of Procedure for the Public Health Agency, 23 May 2018, 1752/ 2014-1.3.1) s 7 .

20 Förordning med instruktion för Myndigheten för samhällsskydd och beredskap (Ordinance with Instruction for the Civil Contingencies Agency, 2008:1002) s 1.

21 Förordning med instruktion för Socialstyrelsen (Ordinance with Instruction for the National Board of Health and Welfare 2015:284) ss 1 and 4. 
decisions involving the use of public power. ${ }^{22}$ In other matters, formal directives, where the Government gives concrete assignments to the authorities, and informal exchanges of views, including a scope for steering from government level to administrative agencies, are permissible. ${ }^{23}$ In public debate, it has been suggested that this accounts for some of the peculiarities of the Swedish strategy against COVID-19. ${ }^{24}$

As to accountability, there is a clear distinction between the government level and the agency level. For government ministers, there is further a distinction between legal and political control. The ministers are under legal supervision by the parliamentary Committee on the Constitution. This body may inquire into alleged deviations from legal requirements and criticise the responsible minister. The ministers are furthermore under the political control of the Riksdag through the parliamentary power of a vote of no-confidence. This is a purely political procedure, where no legal arguments must be put forward. The legality of the actions of administrative agencies and their civil servants is scrutinised by the Justitieombudsman (Parliamentary Ombudsman) and the Justitiekansler (Chancellor of Justice). These bodies may issue decisions, where they put forward public criticism of an agency or a civil servant as a kind of "soft power". 25

\section{NORM-MAKING POWER UNDER THE SWEDish CONSTITUTION}

As stated above, written law holds a central position in the Swedish legal system. Although the Swedish strategy has relied predominantly on individual responsibility and the use of non-binding rules, there are also examples of binding legislation being used to counter the pandemic. In order to understand the scope for non-binding rules, especially in the COVID-19 pandemic, this section explains the legal framework for adopting such binding norms. The focus here is on the fairly detailed and complex provisions of the legislator's norm-making power (Normgivningsmakten), ie the competence to adopt legally binding general norms (föreskrifter) - legislation - on different levels. The legal framework for the adoption of binding norms is laid down in the Instrument of Government. ${ }^{26}$ In this system of central fundamental law, the legal provisions dealt with are considered legally binding. ${ }^{27}$ Non-binding rules are neither prescribed nor prohibited by the Instrument of Government.

Following the principle of popular sovereignty and the constitutional role of the elected parliament as the foremost representative of the people, the constitutional function of adopting legislation lies with the Riksdag, which legislates by adopting an Act of

22 Instrument of Government 1974, Ch 12 Art 2.

23 T Bull, “Administrative Independence and European Integration” (2008) 14 EPL 285; Nergelius, supra, note 7 , pp 84 ff.

24 L Jonung and J Nergelius, "Grundlagen sätter ramarna för Sveriges coronastrategi” Dagens Nyheter (Stockholm, 2 August 2020) <www.dn.se/debatt/grundlagen-satter-ramarna-for-sveriges-coronastrategi> (accessed 30 November 2020).

25 Henrik Wenander, "Administrative Law" in M Bogdan and C Wong (eds), Swedish Legal System (2nd edn, Norstedts Juridik 2021, forthcoming).

26 Nergelius, supra, note 7, pp 27 ff; H Ragnemalm, “Administrative Justice in Sweden” in A Piras (ed), Administrative Law - the Problem of Justice. Vol I, Anglo-American and Nordic Systems (Giuffrè 1991) pp $254 \mathrm{ff}$.

27 Prop (Proposition, Government Bill) 1973:90, 203. 
Law ( Lag) ${ }^{28}$ When allowed for in the fundamental laws, the Riksdag may also delegate the competence to adopt legally binding norms to the government in the form of an Ordinance (Förordning). This delegation of norm-making competence takes the form of a provision in an Act of Law stating that the government may adopt provisions in a certain field or on a certain subject. There are also rather broad possibilities for further delegation of norm-making competence to administrative agencies or to local or regional government (municipalities or regions).

First, the constitutional catalogue of rights is of importance to the distribution of normmaking power. ${ }^{29}$ Certain constitutional rights, such as the prohibition of the death penalty, are absolute in the sense that they may not be limited. Others - such as the freedom of expression, freedom of assembly, freedom of demonstration or Swedish citizens' freedom of movement within the country and freedom to depart the country are designed as relative rights. These may be limited by an ordinary Act of Law following certain parliamentary procedures to safeguard the interests of a minority of the Riksdag. For the most part, the Riksdag may not delegate the competence to adopt norms limiting constitutional rights. An exception is the scope for delegating to the government powers to adopt provisions limiting the freedom of assembly and the freedom to demonstrate, in order to combat an epidemic. This latter scope has been used by the Riksdag in the Public Order Act 1993, which delegates to the government the task of adopting provisions that limit these freedoms. During the COVID-19 pandemic, the Government has made use of this competence and adopted an Ordinance limiting the number of participants in public gatherings (including demonstrations). ${ }^{30}$

Further, concerning rules that do not limit constitutional rights and freedoms, the Instrument of Government establishes a very technical and detailed system for delegation of norm-making competence from the Riksdag to the government. When delegating norm-making competence to the government, the Riksdag may allow the government to sub-delegate this competence to an administrative agency or to local or regional government. ${ }^{31}$ As a result of this intricate system for the formal delegation of legislative power, legally binding norms may be found in Acts of Law, governmental Ordinances or Statutory Instruments adopted by administrative agencies, municipalities or regions (Myndighetsföreskrifter or Kommunala föreskrifter). These regulations all have the same legal status of binding law, although inferior rules shall be set aside if they conflict with superior rules. ${ }^{32}$

The constitutional scope for the delegation of norm-making power is used to a significant extent in Swedish law. During the COVID-19 pandemic, the Riksdag has adopted legislation as a reaction to the pandemic, eg an Act of Law enabling temporary deviations from the legal requirements in corporate law for holding annual

\footnotetext{
28 Instrument of Government 1974, Ch 1 Art 4; Ch 8 Art 1.

29 I Cameron, "Protection of Constitutional Rights in Sweden" (1997) PL 488, gives a thorough overview over the constitutional protection of individual rights under the Instrument of Government.

30 Förordning om förbud mot att hålla allmänna sammankomster och offentliga tillställningar (Ordinance on a Prohibition of Public Gatherings and Public Events, 2020:114), Instrument of Government 1974, Ch 2 Arts 1, 20, 21 and 24; Ordningslag (Public Order Act, 1993:1617), Ch 2 s 15.

31 Instrument of Government 1974, Ch 8 Arts 2.

32 Instrument of Government 1974, Ch 11 Art 14 and Ch 12 Art 10; Nergelius, supra, note 7, p 21.
} 
general meetings of shareholders in a way that minimises the risk of transmitting the coronavirus. ${ }^{33}$ Another current example from the COVID-19 crisis is a temporary prohibition on visits to care homes for the elderly, which was adopted with the legal support of a pre-existing provision in the Social Services Act 2001. ${ }^{34}$ The Riksdag further decided on a broad temporary delegation of norm-making powers to the Government in order to limit the spread of the virus, including the power to close down shopping malls, restaurants, and public transport hubs such as harbours, airports and train stations. ${ }^{35}$ This amendment was adopted via a quick procedure in the Riksdag and featured difficult political negotiations with opposition parties, given that the Government only has the support of a parliamentary minority. ${ }^{36}$ This measure filled a gap in Swedish legislation to some degree, as neither the constitution nor ordinary legislation provides for any norms on declaring a state of emergency or similar, except for situations of war. ${ }^{37}$ The Government never made use of these temporary legislative powers, and they ceased to apply on 30 June 2020. However, they were still of some political importance. In the spring of 2020 , in a possible reference to these powers, the Prime Minister stated that the Government is prepared to make further decisions if it finds that the public demonstrates insufficient respect for non-binding rules. ${ }^{38}$

For rules at all levels, the Swedish constitutional and administrative system requires thorough drafting. These preparations are required to include obtaining the necessary information and hearing from the relevant public authorities and others concerned. ${ }^{39}$ In addition, the rules must be published in either the Svensk författningssamling (for Acts of Law and Ordinances) or the official gazettes of the administrative agencies, municipalities or regions. ${ }^{40}$

The preceding description indicates a formalist view on the norm-making system in Sweden, founded on a hierarchical system of delegation. Given the idea of undivided popular sovereignty, there are no clear features of separations of powers in this system, which rather establishes a "distribution of functions". ${ }^{41}$ It is also possible to

33 Lag om tillfälliga undantag för att underlätta genomförandet av bolags- och föreningsstämmor (Act on Temporary Exceptions in order to Facilitate holding General Meetings in Companies and Associations, 2020:198).

34 Förordning om tillfälligt förbud mot besök i särskilda boendeformer för äldre för att förhindra spridningen av sjukdomen covid-19 (Ordinance on a Temporary Prohibition of Visits to Homes for Elderly People in order to Prevent the Spread of the COVID-19 Disease, 2020:163); Socialtjänstlagen (Social Services Act, 2001:453), Ch 16 s 10.

35 Smittskyddslagen (Communicable Diseases Act, 2004:168), Ch 9 s 6a; A Jonsson Cornell, "Författningsberedskap i praktiken - en kommentar med anledning av lagen om ändring i smittskyddslagen" (2020) Svensk Juristtidning 380.

36 T Nilsson and M Strömberg, "Kristerssons utbrott på Löfven under krismötet" Expressen (Stockholm, 10 April 2020).

37 A Jonsson Cornell and J Salminen, "Emergency Laws in Comparative Constitutional Law - The Case of Sweden and Finland" (2018) 19 German LJ 219, 227.

38 H Olsson, "Stefan Löfven: Inte aktuellt att lätta på restriktioner" Dagens Nyheter (22 April 2020) <www.dn.se/ nyheter/sverige/stefan-lofven-inte-aktuellt-att-latta-pa-restriktioner> (accessed 16 June 2020).

39 Instrument of Government 1974, Ch 4 Art 5 (for the Riksdag) and Ch 7 Art 2 (for the Government); Riksdagsordningen (the Riksdag Act) 2014, Ch 10 Art 2 (for the Riksdag); Förvaltningslag (Administrative Procedure Act, 2017:900) Arts 23 and 26.

40 Instrument of Government 1974, Ch 8 Art 19; Lag (1976:633) om kungörande av lagar och andra författningar; Svensk författtningssamling <www.svenskforfattningssamling.se > (accessed 16 June 2020).

41 O Nyman, “The New Swedish Constitution” (1982) 26 Sc St L 170, 176. 
see this as a pragmatic way of dealing with the more or less universal problem of the scope for legislative delegation.

\section{NON-BINDING RULES}

\section{Introduction}

In addition to the constitutional system for binding norms described above, Swedish law also includes non-binding rules. Perhaps because of the legal tradition focusing on written and binding norms, legal scholarship has not given much attention to the phenomenon of rules of this kind. ${ }^{42}$ Below, some general comments are made regarding the treatment of non-binding rules in Swedish constitutional and administrative law, primarily discussing the general legal framework for such rules as established in legislation and legislative materials. The non-binding instruments addressed below fall into either the formal category of General Recommendations (Allmänna råd) or the vaguer category of "other kinds" of guidance documents. ${ }^{43}$ The use of such instruments in the COVID-19 pandemic will be elaborated in Section VI.

\section{General Recommendations}

Although non-binding instruments, as mentioned, are not dealt with in the Instrument of Government, they clearly form a part of the Swedish legal system. The travaux préparatoires to the legislation governing the publication of legal provisions establishes that, just as in the case of binding norms, the category of General Recommendations (Allmänna råd) constitutes "rules" (regler). ${ }^{44}$ In this way, the category of non-binding rules is formalised. According to the Ordinance on Official Gazettes, the term General Recommendations denotes "general recommendations on the application of a statute (Act of Law or delegated legislation), which state how someone may or ought to act in a certain regard". ${ }^{45}$ General Recommendations may in this way summarise case law by the Supreme Administrative Court or otherwise suggest how to assess certain situations within the wording of the applicable legislation.

General Recommendations are adopted by administrative agencies and may be directed to both individuals and administrative agencies. For the administrative agencies and their employees, General Recommendations have the function of promoting uniformity in decision-making. Although General Recommendations are not considered legally binding - not even on the issuing agency itself - the agency's adherence to General Recommendations serves the interests of predictability and citizens' legitimate expectations. ${ }^{46}$ Legal scholarship has described these

\footnotetext{
42 See however F Sterzel, Författning $i$ utveckling (Iustus 2009) pp $261 \mathrm{ff}$; some brief remarks on the concept of "General Recommendations" are also made by Ragnemalm, supra, note 26, p 262; J Nergelius, Svensk statsrätt (4th edn, Studentlitteratur 2018) p 113.

43 U von Essen et al, Förvaltningsrättens grunder (3rd edn, Norstedts Juridik 2018) pp 54 ff.

44 Prop 1975/76:112, $66 \mathrm{f}$.

45 Författningssamlingsförordning (Ordinance on Official Gazettes, 1976:725) s 1 (author's translation).

46 R Påhlsson, "Skatteverkets styrsignaler - en ny blomma i regelrabatten" (2006) Skattenytt 401, 404.
} 
recommendations as placed "at least one step below the binding norms". ${ }^{47}$ General Recommendations are considered important in the everyday work of the authorities, as they concretise the legislation for practical use by civil servants, who are not necessarily trained as lawyers. ${ }^{48}$

In contrast to the binding Statutory Instruments adopted by administrative agencies, the formal delegation of norm-making power is not required for an administrative agency to adopt General Recommendations. ${ }^{49}$ Because the adoption of General Recommendations does not mean applying provisions in Acts of Law or making decisions involving the use of public power (see Section II on the constitutional limits for involving the government in such matters), the government may also - in the tradition of pragmatism - steer the agency by maintaining "informal contacts" and give its view on how the agency ought to proceed when issuing General Recommendations. Under the Swedish Administrative Model, however, formal decision-making still lies with the agency (see Section I).

Under the requirement of legality, in the Administrative Procedure Act 2017, "an administrative agency may only take measures that have support in the legal order". 50 In practice, this means that the measures must fall within the agency's field of competence. Governmental Ordinances regulating the work of administrative agencies, so-called Instructions (instruktioner), normally establish the fields in which the agency shall be competent to act. Concerning the COVID-19 crisis, the Instruction for the Public Health Agency explicitly states that the agency is responsible for issuing General Recommendations within its fields of competence. ${ }^{51}$ Also, as always, the administrative agencies are required to observe objectivity, impartiality and proportionality in their activities. ${ }^{52}$ Furthermore, general requirements on thorough drafting of administrative decisions also apply to General Recommendations. This may include involving concerned individuals or other agencies. $^{53}$

Concerning the relationship between General Recommendations and binding norms, the principle of legality implies that the General Recommendations must not go beyond the provisions of the binding norms ${ }^{54}$ For example, the Parliamentary Ombudsman has criticised the Swedish Social Insurance Agency (Försäkringskassan) for adopting rules that effectively set aside a provision of the Social Insurance Code 2010 (an Act of Law). ${ }^{55}$

\footnotetext{
47 Nergelius, supra, note 42, p 113.

48 L Bejstam, "Kan allmänna råd ändras när och hur som helst?" (2000) Förvaltningsrättslig Tidskrift 23, 24 f; Von Essen et al, supra, note 43, p 54.

49 Prop 1983/84:119, 7; E Holmberg et al, Grundlagarna. Regeringsformen, successionsordningen, riksdagsordningen (3rd edn, Norstedts Juridik 2012) p 353.

50 Förvaltningslag (Administrative Procedure Act, 2017:900), s 5.

51 Ordinance with Instruction for the Public Health Agency 2013, s 5.

52 Administrative Procedure Act 2017, s 5.

53 Administrative Procedure Act 2017, ss 23-26.

54 Påhlsson, supra, note 46, p 411.

55 Decision 15 June 2020, 6172-2018 <www.jo.se/PageFiles/15442/6172-2018.pdf> (accessed 30 November 2020); Socialförsäkringsbalken (Social Insurance Code, 2010:110).
} 
According to the Ordinance on Official Gazettes, General Recommendations shall be printed or duplicated and made available to the public. They may be published together with the binding Statutory Instruments adopted by the administrative agency in that agency's Official Gazette. If this method of publication is used, the binding norms and non-binding rules shall be clearly distinguished in the text. ${ }^{56}$ Although not required by the Ordinance, many authorities now also publish their General Recommendations on their websites.

The constitutional requirement of support in legislation (or delegated norms) for individuals' obligations towards the state implies that General Recommendations cannot form the legal basis for any duties that are not laid down in legislation. ${ }^{57}$ Still, General Recommendations may be of indirect importance. The case law of the Supreme Administrative Court indicates that General Recommendations constitute default rules, from which the authorities may depart if the situation in a given case demands it. ${ }^{58}$ Although the need for uniform decision-making calls for the use of non-binding rules in this way, it also illustrates a conflict between the formal system for norm-making and the pragmatic use of non-binding rules. ${ }^{59}$

The use of General Recommendations has been criticised for blurring the line between binding and non-binding measures. A governmental inquiry proposed in 2007 that the formal category of General Recommendations should be abolished. When necessary, the Riksdag and Government would instead delegate and sub-delegate formal norm-making competence to the authorities. ${ }^{60}$ This proposal, however, did not lead to legislative change.

\section{Other kinds of guidance documents}

In addition to General Recommendations, there are also other kinds of non-binding documents providing guidance (Rekommendationer) by administrative agencies. ${ }^{61}$ These documents are not covered by the requirements for General Recommendations described above. Guidance documents may take the form of memoranda, leaflets, webpages, etc. There are no specific legal provisions on the scope for administrative agencies to issue such guidance documents. To a great extent, however, guidance documents fall under the same kind of requirements on legality, objectivity, impartiality and proportionality as General Recommendations, and the distinction between the two categories is not always clear. ${ }^{62}$ An important difference, however, is that the limitation of how someone "may or ought to" apply a statute does not apply to guidance documents.

A special form of guidance is provided by the Ministry for Foreign Affairs, which may provide travel information to Swedes going abroad. In this way, the Ministry and its embassies can advise against travel to certain countries because of the security

\footnotetext{
56 Ordinance on Official Gazettes, s 27.

57 W Warnling-Nerep, "Finansinspektionens tillsyn i perspektiv av legalitet och legitimitet" (2009) Förvaltningsrättslig Tidskrift 389, 401.

58 RA 2008 ref 27; RA 2009 ref 20; Sterzel, supra, note 42, p 265.

59 Påhlsson, supra, note 46, p 121.

60 SOU 2007:10 Hållbar samhällsorganisation med utvecklingskraft, 96 f.

61 Von Essen et al, supra, note 43, p 55.

62 Påhlsson, supra, note 46, p 96.
} 
situation. This kind of advice is also important for travel agencies and insurance companies, which take such advice into account when considering refunds on package tours. ${ }^{63}$ Such advice from the Ministry may be legally explained by the broad mandate of the Ministry to safeguard the rights and interests of Swedes in foreign countries. ${ }^{64}$

\section{LEGAL PROTECTION AGAINST NON-BINDING RULES}

This section gives a general overview of the various forms for legal protection against non-binding rules. The possible implications of the Swedish measures countering COVID-19 will be dealt with in Section VI.

When it comes to legal protection against non-binding rules, it should first be considered whether it is possible to challenge the adoption of non-binding rules before a court (direct review). The rules of the Administrative Procedure Act allow for appeals of all kinds of administrative decisions. However, for someone to be able to appeal an administrative decision, this decision must fulfil the criteria for appeal, which include a requirement that the decision affects someone's situation "in a not insignificant way". The appellant further needs to be affected personally in order to have standing. ${ }^{65}$ Given the general and non-binding character of General Recommendations, it is unlikely that individuals would be affected to the extent necessary for them to be able to challenge the adoption of these recommendations. ${ }^{66}$

However, under the case law of the Supreme Administrative Court, there may still be some scope for a direct review of non-binding recommendations, provided that the decision has factual effects on individuals. ${ }^{67}$ The Supreme Administrative Court case RA 2004 ref 8, "The Olive Oil Case", establishes a possible route for challenging non-binding decisions. In that case, the Swedish Food Agency (Livsmedelsverket) had disseminated information that certain designated olive oil products were unfit for consumption. The Supreme Administrative Court noted that the Agency has the task of providing information to the public. The Court held that the information did not constitute a legally binding measure prohibiting the sale of the olive oil products. Nevertheless, the information was likely to be understood as "binding". Owing to its factual effects, it could be challenged before an administrative court. The Supreme Administrative Court held that the Food Agency had exceeded its competence by blurring its two distinct functions of providing information and making formal decisions on food safety.

The Olive Oil Case may be seen as an example of a legal-realist approach to law. Instead of using formal concepts such as binding/non-binding, the Court considered

\footnotetext{
63 Ministry for Foreign Affairs - a brief presentation (Ministry for Foreign Affairs 2020) <www.government.se> (accessed 30 November 2020).

64 Förordning med instruction för Regeringskansliet (Ordinance with Instruction to the Government Offices, 1996:1515), annex para 3.1.

65 Administrative Procedure Act 2017, ss 41 and 42.

66 cf Prop 2016/17:180 En modern och rättssäker förvaltning - ny förvaltningslag 258 on the lack of standing for challenging Statutory Instruments.

67 Administrative Procedure Act 2017, s 41.
} 
the factual effects on, and the understanding of, the measures taken by the individuals concerned. Taking this approach, other kinds of formally non-binding measures may also be assessed by a court. Still, as for all appeals of administrative decisions, an appellant needs to be sufficiently affected on a personal level to have standing. ${ }^{68}$

The use of General Recommendations may also be scrutinised by an administrative court after appeal of a decision where the decision involves the use of non-binding rules (indirect review). Generally, the review of the administrative court also covers matters of suitability and the administrative agency's use of discretion. ${ }^{69}$

A further possibility of obtaining an indirect review of non-binding rules is to raise a claim for damages from the state under the Tort Liability Act when an agency has taken measures in part based on such rules. The Act further entails a possibility of economic redress from the state when an agency gives faulty advice. ${ }^{70}$ It is difficult, however, to imagine situations where General Recommendations or guidelines of the kind discussed here could be faulty in the sense of the latter provision.

\section{The USE OF NON-BINDING RULES IN THE PANDEMIC}

The central piece of legislation for combating the COVID-19 pandemic in Sweden is the Communicable Diseases Act 2004. ${ }^{71}$ The Act is based on respect for the equal rights of all people and for personal integrity. The main focus of the Act is on voluntary and preventive measures, with the responsibility placed explicitly on the individual: "Everyone shall contribute to preventing the transmission of communicable diseases by being attentive and taking reasonable safety measures." 72 Thus, to a significant degree, the Swedish strategy for combating COVID-19 was predetermined by the 2004 Act opting for these principles. ${ }^{73}$

\section{General Recommendations and other kinds of guidance documents}

Apart from certain binding Statutory Instruments not discussed here, the Public Health Agency has adopted COVID-19 specific General Recommendations relating to everyone's responsibility to prevent transmission of communicable diseases under the relevant Act. The recommendations include directions, among other things, on:

- Washing hands often and at least for 20 seconds each time,

- Keeping appropriate distance from other people,

- Avoiding public transport where a seat reservation is not possible,

\footnotetext{
68 Administrative Procedure Act 2017, s 42.

69 H Wenander, "Full Judicial Review or Administrative Discretion? A Swedish Perspective on Deference to the Administration" in G Zhu (ed), Deference to the Administration in Judicial Review (Springer 2019) p 409.

70 Skadeståndslag (Tort Liability Act, 1972:207), Ch 3 ss 2 and 3; B Bengtsson, "Government Liability in Sweden" (2001) 41 Scandinavian Studies in Law 55, 58.

71 Smittskyddslag (Communicable Diseases Act, 2004:168).

72 Communicable Diseases Act 2004, Ch 2 s 1; cf Prop 2003/04:30 Ny smittskyddslag mm, 84 f.

73 O Peterson, "Sverige valde coronastrategi med 2004 års smittskyddslag" Dagens Nyheter (Stockholm, 8 June 2020) <www.dn.se/debatt/sverige-valde-coronastrategi-med-2004-ars-smittskyddslag > (accessed 30 November 2020).
} 
- Avoiding participation in major social events such as parties, funerals, christenings and weddings,

- Working, if possible, from home, and

- Avoiding unnecessary travel. ${ }^{74}$

Interestingly, the point on travel restrictions in practice may be seen as limiting the constitutionally entrenched right of free movement, even though there are no sanctions for deviating from the recommendations. I come back to this below.

General Recommendations have been published in the Official Gazette used by the Public Health Agency and on the Agency's website, as well as on easily accessible posters and leaflets that can be printed at home or at workplaces. Such information with reference to the Agency has been omnipresent in Sweden in the spring and summer of 2020. The Public Health Agency, represented by the State Epidemiologist, has provided information on the development of the COVID-19 situation in Sweden through regular joint press briefings with the Government, the Civil Contingencies Agency and the National Board of Health and Welfare.

Although the non-binding status of the General Recommendations is clear from a legal point of view, there has been a certain degree of confusion in public debates regarding the meaning of the concept of a "General Recommendation". For example, the Director General of the Public Health Agency was quoted stating that General Recommendations are binding. ${ }^{75}$ The legal subtlety that they are in fact not binding, whereas the legislation they explain is, may understandably have escaped many. In mass media and even in press briefings by the relevant agencies and the Government, General Recommendations have very often been discussed as "prohibitions", etc, and for the most part, their character as non-binding has not been stressed.

In addition to the formal category of General Recommendations, the Government and the Public Health Agency have also given other kinds of guidance. For example, the Public Health Agency has provided more specific information on its website. This form of guidance has covered matters such as how long to stay at home after recovering from illness, and coughing and sneezing into one's elbow. ${ }^{76}$

Curiously, the Prime Minister has also spoken, on at least one occasion, to the meaning of General Recommendations. At a press briefing on 13 May 2020, Prime Minister Stefan Löfven stated that the recommendation to avoid unnecessary travel was now to be understood as a recommendation to avoid travelling within Sweden further away from home than a two-hour car ride. ${ }^{77}$ Seemingly, this time limit was not laid down in any General Recommendation or other guidance document. As the changes in the

\footnotetext{
74 Folkhälsomyndighetens föreskrifter och allmänna råd om allas ansvar att förhindra smitta av covid-19 m.m. (the Public Health Agency's Statutory Instruments and General Recommendations on Everyone's Responsibility to prevent the Transmission of COVID-19 etc, HSLF-FS [Gemensam författningssamling avseende hälso- och sjukvård, socialtjänst, läkemedel, folkhälsa m.m.], 2020:12) in its original version; cf Communicable Diseases Act 2004, Ch 2 s 1 .

75 A Häggström, "Folkhälsomyndighetens nya riktlinjer för hela 2020" Expressen (1 April 2020) <www.expressen. se/nyheter/coronaviruset/folkhalsomyndighetens-nya-riktlinjer-for-hela-2020> (accessed 25 June 2020).

76 Eg (in English) "FAQ about COVID-19" <www.folkhalsomyndigheten.se/the-public-health-agency-of-sweden/ communicable-disease-control/covid-19> (accessed 6 August 2020).

77 Regeringskansliet (Government Offices), "Pressträff med statsministern 13 maj" <www.regeringen.se/ pressmeddelanden/2020/05/presstraff-med-statsministern-13-maj> (accessed 26 June 2020).
} 
General Recommendations or other forms of guidance have normally been announced at the joint press briefings, it has not always been clear whether they come from the Government or from the Public Health Agency. Furthermore, it has been remarked that the Prime Minister should have clarified that this was only a recommendation and not a binding limitation on the constitutional freedom of movement. ${ }^{78}$

As could be expected, the information on travel advice from the Ministry for Foreign Affairs was also adjusted to reflect the COVID-19 situation. On 14 March 2020, the Ministry issued advice against non-essential travel to all countries. The advice was subsequently lifted for a number of European countries, but still applied as of August 2020 in relation to several other countries, including all countries outside Europe. ${ }^{79}$ Like the Prime Minister, the Minister for Foreign Affairs was criticised for not being clear on the non-binding character of the travel advice. ${ }^{80}$

\section{The response of the public to the restrictions}

The overall view is that the public has been very responsive to the General Recommendations and other kinds of guidance provided by the authorities, mostly those issued by the Public Health Agency. In April 2020, the Government summarised its view:

People in Sweden have a high level of trust in government agencies. This means that a large proportion of people follow government agencies' advice. In the current situation, people in Sweden are on the whole acting responsibly to reduce the spread of infection by, for example, restricting their social contacts. ${ }^{81}$

More specifically, a survey based on interviews conducted by the Public Health Agency indicated that over 80 per cent of the population have changed their behaviour during the pandemic. Around 87 per cent keep a distance from others both indoors and outdoors. ${ }^{82}$ However, it is beyond the scope of this article to verify these results, or to conclude that this change in behaviour is a clear effect of the recommendations.

As far as can be established, no cases relating to the use of non-binding rules have been decided by the Swedish courts or the Parliamentary Ombudsman as of August 2020. However, the approach of the Supreme Administrative Court in the Olive Oil Case may be relevant for the future handling of challenges to administrative agencies' formally non-binding measures in the pandemic. Also, it is possible that the scope for

\footnotetext{
78 Jonung and Nergelius, supra, note 24

79 Ministry for Foreign Affairs, "Changes to the advice against non-essential travel to a number of countries in Europe" <www.government.se/press-releases/2020/07/changes-to-the-advice-against-non-essential-travel-to-anumber-of-countries-in-europe $>$ (accessed 3 August 2020).

80 Jonung and Nergelius, supra, note 24.

81 Government Offices, "Strategy in response to the COVID-19 pandemic" (Government Offices, 6 April 2020), $<$ www.government.se/articles/2020/04/strategy-in-response-to-the-pandemic > (accessed 26 June 2020).

82 Folkhälsomyndigheten, "Stor majoritet har anpassat sitt beteende under pandemin" (Folkhälsomyndigheten, 23 June 2020) <www.folkhalsomyndigheten.se/nyheter-och-press/nyhetsarkiv/2020/juni/stor-majoritet-har-anpassat-sittbeteende-under-pandemin $>$ (accessed 30 November 2020).
} 
other forms of judicial review, such as claims for damages, involves a legal assessment of non-binding rules.

\section{Concluding REMARKs}

As is clear from the preceding discussion, Sweden's strategy to combat the COVID-19 pandemic has been very much based on non-binding instruments. From a legal point of view, there are several explanations for this. The use of non-binding instruments is explained by both formal aspects of the Swedish Administrative Model, with independently organised administrative agencies and with pragmatic considerations relating to the need to find quick, practical solutions.

In respect of the Swedish Administrative Model, it could first be observed that this constitutional arrangement means that the delegation of norm-making power from the parliament to the government, and even further to administrative agencies, is a recurrent feature in Swedish law. Conferring the power on Public Health Agency experts to make decisions with far-reaching effects is well in line with this. Second, it is commonplace that administrative agencies issue non-binding rules within their fields of competence. From a more practical perspective, at the start of the pandemic, the Swedish Government found itself without any mandate to decide on a general lockdown and strict measures of the kind used in other countries, including its Nordic neighbours. Given the focus on written legislation as the core of the legality principle, neither the existing legislation nor constitutional principles on extraordinary powers of the government provided support for such measures in Sweden.

The wide use of non-binding rules during the pandemic in Sweden may also be seen as a consequence of the constitutional choice of basing the constitution on undivided popular sovereignty, rather than some form of separation of powers. This does not imply that Sweden in general demonstrates deficiencies when it comes to the constitutional protection of individual rights. Still, the lack of constitutional distinction between the roles of the legislative and executive powers may account for the wide scope left to the Public Health Agency for the task of adopting both binding and non-binding rules. Furthermore, the legislative choice behind the Communicable Diseases Act 2004 - emphasising the responsibility of the individual (Section V) reinforced this tendency to focus on non-binding measures, rather than formal prohibitions and similar rules.

As was noted above (Section VI.1), there are some examples of General Recommendations and other kinds of guidance by the Public Health Agency and the Ministry for Foreign Affairs that have the practical effect of limiting constitutional rights, such as the right to free movement within Sweden and abroad. From a legal perspective, this is pragmatism taken one step too far.

As has been elaborated here, there has been some confusion in the public debate on the status of General Recommendations. The confusion is understandable, as these recommendations concern the meaning of the binding norms and may be published together with binding Statutory Instruments. Their non-binding status means that they rarely give rise to claims that may be enforced through a court procedure; after all, no 
one is obliged to adhere to the rules, although the general public may expect their fellow people to do so. In general discourse in society, these recommendations are seemingly treated as legislation, and the public seems to follow them. This illustrates the tension between formalism and pragmatism that is inherent in Swedish public law.

There are also further grounds for criticism. The use of General Recommendations is confusing from a legal perspective. Whereas the legal method normally provides for ordering arguments and limiting the use of public power under a certain degree of formalism, the "pragmatic" use of non-binding rules blurs these distinctions. It further provides for a form of soft governance, without a clear legal framework for accountability and control. As to legal protection, the case law of the Supreme Administrative Court - seemingly inspired by Scandinavian legal realism - provides an opportunity to challenge some formally non-binding decisions. At the time of writing, however, this feature of the Swedish legal system has not yet been used. Still, the approach may balance at least some of the unfortunate combined effects of Swedish formalism and pragmatism. 